This is an Open Access article, distributed under the terms of the Creative Commons Attribution licence (http://creativecommons.org/licenses/by/4.0/), which permits unrestricted re-use, distribution, and reproduction in any medium, provided the original work is properly cited.

\title{
Isotopic Evidence for Human Movement into Central England during the Early Neolithic
}

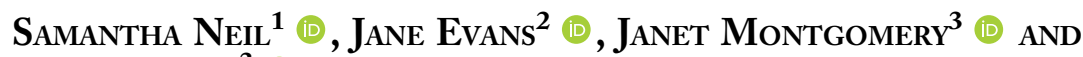 \\ Chris SCARRE ${ }^{3}$ \\ ${ }^{1}$ School of Archaeology, University of Oxford, UK \\ ${ }^{2}$ National Environmental Isotope Facility, Nottingham, UK \\ ${ }^{3}$ Department of Archaeology, Durham University, UK
}

Isotope ratios of tooth enamel from ten Early Neolithic individuals buried in a long cairn at Whitwell in central England were measured to determine where they sourced their childhood diet. Five individuals have low $\mathrm{Sr}$ concentrations (11-66 ppm) and high ${ }^{87} \mathrm{Sr}{ }^{86} \mathrm{Sr}$ ratios (0.7164-0.7212). Three individuals bave relatively low ${ }^{87} \mathrm{Sr}{ }^{86} \mathrm{Sr}$ ratios $(0.712-0.711)$ and $\mathrm{Sr}$ concentrations ranging between 54 and $109 \mathrm{ppm}$. Two individuals have strontium isotope values that bridge the gap between the isotope compositions of these two groups. The high ${ }^{87} \mathrm{Sr}{ }^{86} \mathrm{Sr}$ values are rare in human enamel and exclude sources within the biosphere of central England. Oxygen isotope values are comparable to those found within human archaeological populations buried in temperate regions of Europe. The strontium isotope results should be interpreted in the context of other evidence for migration from northern France to Britain during the Early Neolithic.

Keywords: migration, Neolithic, Britain, strontium, oxygen, isotopes

\section{INTRODUCTION}

Radiocarbon dating indicates that farming became established in Britain during the first few centuries of the fourth millennium BC (Bayliss et al., 2011: 833-36; Bradley et al., 2015). This change defines the onset of the British Neolithic. The transition to an agricultural subsistence regime was associated with the importation of non-native domesticated species of plants and animals from the European mainland, including sheep and cereals (Tresset \& Vigne, 2011: 184; Tresset, 2015). This was accompanied by a radical transformation in both technology and culture during the early fourth millennium $\mathrm{BC}$, with the introduction of new traditions into Britain from the European mainland, including pottery production and the construction of burial monuments (Scarre, 2015).

There has long been debate as to whether farming was introduced into Britain by the arrival of farmers from the European mainland or through the adoption of domesticates by local British hunter-gatherer communities. Recent comparative analysis of pottery suggests that new traditions and practices were introduced during the early fourth 
millennium $\mathrm{BC}$ from at least two regions of the European mainland: the Picardie/Pas de Calais area of northern France, and Brittany and Lower Normandy in northwestern France (Pioffet, 2015; see also Sheridan, 2010a, 2010b). Analysis of ancient DNA from preserved skeletal material also indicates a substantial measure of population movement at the onset of the Neolithic throughout western Europe, including Britain (Hofmanová et al., 2016; Brace et al., 2019). Here we use strontium $\left({ }^{87} \mathrm{Sr} /{ }^{86} \mathrm{Sr}\right)$ isotope and oxygen $\left(\delta^{18} \mathrm{O}\right)$ isotope analysis to evaluate from what region or locality certain individuals buried in Britain during the fourth millennium BC obtained their childhood diets. We compare isotope ratios in tooth enamel from ten individuals buried at the Whitwell long cairn in the East Midlands of England to mapped modern bioavailable values and to previously published data from earlier Neolithic burial populations from other areas within England and Wales. The results support the argument for the movement of individuals over long distances during the Early Neolithic. They also shed light on mobility patterns during the development of the Neolithic in Britain in the early fourth millennium BC.

\section{Site Details}

The samples in this study come from the cairn at Whitwell (Figure 1), located some $20 \mathrm{~km}$ north of Nottingham in central England in the county of Derbyshire (OS GB Grid SK53207482). It is one of the few Early Neolithic burial monuments in Britain to have been totally excavated to modern archaeological standards. Following its discovery during quarrying activity that had destroyed the southeastern end of the structure, the remainder of the monument was fully excavated between 1988 and 1991 (Vyner \& Wall,
2011). Burials were found within a linear mortuary structure and a circular cairn, both under a trapezoidal mound. The linear mortuary structure was used for the collective burial of multiple individuals. Over 900 bone fragments and disarticulated skeletal elements were recovered, representing a minimum number of sixteen individuals (twelve adults and four children) (Chamberlain \& Witkin, 2011: 71-73). Radiocarbon dating indicates that burial activity at Whitwell began in the thirty-eighth century BC (Vyner \& Wall, 2011). The remains of a small number of individuals, found stratified under a series of limestone slabs within the linear mortuary enclosure, have been dated to 37803700 cal BC (5 per cent probability; Griffiths, 2011: 85; Vyner \& Wall, 2011). One individual associated with this phase, which is thought to represent the first use of the monument for burial, had dentition that was suitable for sampling (see sample selection protocol within the Materials and Methods section below). Following the placement of the limestone slabs, the linear mortuary enclosure continued to be used for burial. Five individuals associated with this phase of use (phase 4B/5), dated to $3720-3650$ cal BC (95 per cent probability; Vyner \& Wall, 2011: 29-30), had dentition suitable for sampling. The remains of three other individuals sampled for the present study were also found within the linear mortuary structure but could not be assigned by the excavators to a specific stratigraphic context. They could have been buried either before or after placement of the limestone slabs (Table 1). Modelled radiocarbon dates, drawing on a sample of stratigraphically unrelated skeletal elements from the linear mortuary structure, suggest that these remains may date to $3760-3660 \mathrm{cal} \mathrm{BC}$ (95 per cent probability; Griffiths, 2011: 85).

The oval cairn next to the linear mortuary structure within the long mound (Figure 1) 


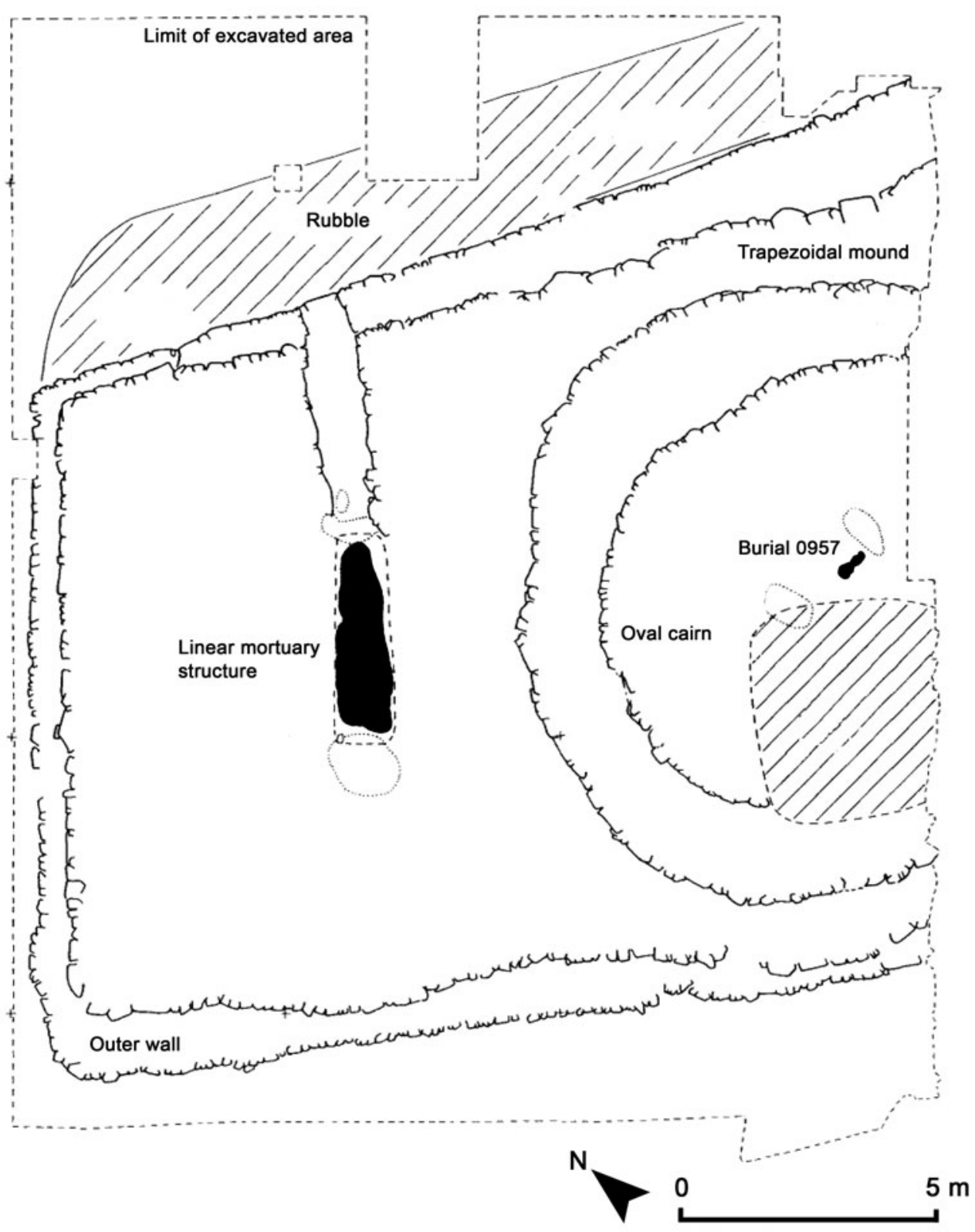

Figure 1. Plan of the Whitwell cairn. Reproduced with permission, after Vyner \& Wall (2011: fig. 5).

contained the burial of a single individual, a young woman (0957) who died at approximately 16-17 years of age (Chamberlain \& Witkin, 2011: 74-75) in 3770-3670 cal BC (95 per cent probability; Griffiths, 2011: 85).

\section{Isotope ConstrainTs on Location and Surrounding Area}

The Whitwell cairn is located in central England where the geology is dominated 
Table 1. Results of ${ }^{87} \mathrm{Sr}{ }^{86} \mathrm{Sr}, \delta^{18} \mathrm{O}_{\text {carbonate }}$ and $\delta^{13} C_{\text {carbonate }}$ analysis of tooth enamel from the Whitwell cairn. All teeth are from the mandibular dentition: $L=$ left; $R=$ Right; $M 1=$ permanent first molar; $M 2=$ permanent second molar; $M 3=$ permanent third molar; $G=$ canine. Phasing and contexts for skeletal remains are as documented by the excavators (Vyner $\mathcal{E}^{2}$ Wall, 2011). U = stratigraphically unassociated skeletal remains excavated from the linear mortuary structure.

Radiocarbon dating of a sample of stratigraphically unassociated remains from the linear mortuary structure estimates that they date to between 3760-3660 cal BC (95 per cent probability; Griffiths, 2011: 85).

\begin{tabular}{|c|c|c|c|c|c|c|c|c|c|c|}
\hline $\begin{array}{l}\text { Museum } \\
\text { accession } \\
\text { number }\end{array}$ & Location & Phas & age at death & Tooth & $\begin{array}{l}\mathrm{Sr} \\
(\mathrm{mg} / \mathrm{kg})\end{array}$ & ${ }^{87} \mathrm{Sr} /{ }^{86} \mathrm{Sr}$ & $\begin{array}{c}\delta^{13} C_{\text {carbonate }} \% \text { o } \\
\text { VPDB enamel }\end{array}$ & $\begin{array}{c}\delta^{18} \mathrm{O}_{\text {carbonate }} \\
\text { VPDB }\end{array}$ & $\begin{array}{c}\delta^{18} O_{\text {carbonate }} \% \\
\text { VSMOW }\end{array}$ & $\begin{array}{c}\delta^{18} \mathrm{O}_{\text {phosphate }} \% \text { o } \\
\text { VSMOW }\end{array}$ \\
\hline WHIT 0534 & Linear mortuary structure & $2 \mathrm{~B}$ & adult & $\begin{array}{l}\text { LM1 } \\
\text { LM2 }\end{array}$ & $\begin{array}{l}19 \\
26\end{array}$ & $\begin{array}{l}0.7127 \\
0.7168\end{array}$ & $\begin{array}{l}-16.5 \\
-15.7\end{array}$ & $\begin{array}{l}-3.4 \\
-3.9\end{array}$ & $\begin{array}{l}27.4 \\
26.9\end{array}$ & $\begin{array}{l}18.6 \\
18.1\end{array}$ \\
\hline WHIT 0487 & Linear mortuary structure & $\mathrm{U}$ & sub-adult (12-15 yrs) & $\begin{array}{l}\text { RM1 } \\
\text { RM2 }\end{array}$ & $\begin{array}{l}28 \\
24\end{array}$ & $\begin{array}{l}0.7205 \\
0.7207\end{array}$ & $\begin{array}{l}-15.6 \\
-17.5\end{array}$ & $\begin{array}{l}-3.9 \\
-4.0\end{array}$ & $\begin{array}{l}26.9 \\
26.8\end{array}$ & $\begin{array}{l}18.1 \\
18.0\end{array}$ \\
\hline WHIT 0543 & Linear mortuary structure & $4 \mathrm{~B} / 5$ & sub-adult (12-15 yrs) & $\begin{array}{l}\text { RM1 } \\
\text { RM2 }\end{array}$ & $\begin{array}{l}60 \\
66\end{array}$ & $\begin{array}{l}0.7207 \\
0.7183\end{array}$ & $\begin{array}{l}-17.2 \\
-16.7\end{array}$ & $\begin{array}{l}-4.1 \\
-4.1\end{array}$ & $\begin{array}{l}26.7 \\
26.7\end{array}$ & $\begin{array}{l}17.9 \\
17.8\end{array}$ \\
\hline WHIT 0420/1 & Linear mortuary structure & $\mathrm{U}$ & adult & $\begin{array}{l}\text { LM2 } \\
\text { LM3 }\end{array}$ & $\begin{array}{r}109 \\
80\end{array}$ & $\begin{array}{l}0.7113 \\
0.7127\end{array}$ & $\begin{array}{l}-15.6 \\
-15.5\end{array}$ & $\begin{array}{l}-3.5 \\
-4.2\end{array}$ & $\begin{array}{l}27.3 \\
26.6\end{array}$ & $\begin{array}{l}18.5 \\
17.8\end{array}$ \\
\hline WHIT 0451 & Linear mortuary structure & $\mathrm{U}$ & sub-adult (10-11 yrs) & $\begin{array}{l}\text { RM1 } \\
\text { RM2 }\end{array}$ & $\begin{array}{l}23 \\
30\end{array}$ & $\begin{array}{l}0.7186 \\
0.7204\end{array}$ & $\begin{array}{l}-16.6 \\
-16.2\end{array}$ & $\begin{array}{l}-3.7 \\
-4.9\end{array}$ & $\begin{array}{l}27.1 \\
25.9\end{array}$ & $\begin{array}{l}18.3 \\
17.1\end{array}$ \\
\hline WHIT 0334 & Linear mortuary structure & $4 \mathrm{~B} / 5$ & adult & $\begin{array}{l}\text { LM1 } \\
\text { LM2 }\end{array}$ & $\begin{array}{l}24 \\
49\end{array}$ & $\begin{array}{l}0.7187 \\
0.7212\end{array}$ & $\begin{array}{l}-16.5 \\
-16.8\end{array}$ & $\begin{array}{l}-4.3 \\
-3.7\end{array}$ & $\begin{array}{l}26.5 \\
27.1\end{array}$ & $\begin{array}{l}17.7 \\
18.2\end{array}$ \\
\hline WHIT 0512/2 & Linear mortuary structure & $4 \mathrm{~B} / 5$ & adult & $\begin{array}{l}\text { LM2 } \\
\text { LM3 }\end{array}$ & $\begin{array}{l}85 \\
91\end{array}$ & $\begin{array}{l}0.7116 \\
0.7124\end{array}$ & $\begin{array}{l}-16.2 \\
-15.7\end{array}$ & $\begin{array}{l}-3.9 \\
-3.9\end{array}$ & $\begin{array}{l}26.9 \\
26.9\end{array}$ & $\begin{array}{l}18.1 \\
18.1\end{array}$ \\
\hline WHIT 0219 & Linear mortuary structure & $4 \mathrm{~B} / 5$ & adult & $\begin{array}{l}\text { LM1 } \\
\text { LM2 } \\
\text { LM3 }\end{array}$ & $\begin{array}{l}19 \\
35 \\
21\end{array}$ & $\begin{array}{l}0.7176 \\
0.7185 \\
0.7169\end{array}$ & $\begin{array}{l}-16.5 \\
-16.9 \\
-16.0\end{array}$ & $\begin{array}{l}-3.2 \\
-4.3 \\
-3.9\end{array}$ & $\begin{array}{l}27.6 \\
26.5 \\
26.9\end{array}$ & $\begin{array}{l}18.8 \\
17.6 \\
18.1\end{array}$ \\
\hline WHIT 0359/1 & Linear mortuary structure & $4 \mathrm{~B} / 5$ & adult & $\mathrm{RC}$ & 54 & 0.7107 & -15.9 & -4.1 & 26.7 & 17.9 \\
\hline WHIT 0957 & Circular cairn & & $16-17 \mathrm{yrs}$ & $\begin{array}{l}\text { LM1 } \\
\text { LM2 } \\
\text { RM3 }\end{array}$ & $\begin{array}{l}11 \\
18 \\
73\end{array}$ & $\begin{array}{l}0.7164 \\
0.7192 \\
0.7105\end{array}$ & $\begin{array}{l}-16.4 \\
-16.0 \\
-15.5\end{array}$ & $\begin{array}{l}-4.0 \\
-4.0 \\
-4.2\end{array}$ & $\begin{array}{l}26.8 \\
26.8 \\
26.6\end{array}$ & $\begin{array}{l}18.0 \\
17.9 \\
17.8\end{array}$ \\
\hline
\end{tabular}


by Permian, Carboniferous, and Triassicage sediments. The Permian comprises marls, sandstone, and the Cadeby Formation, on which the cairn was constructed, and these give interquartile ranges respectively of $0.7096-0.7106(\mathrm{n}=$ 4), 0.7096-0.7106 $(\mathrm{n}=15)$, and 0.7087$0.7096(n=7)$. There are overlying Quaternary loess deposits in places. Biosphere samples taken on Triassic rocks generate an interquartile range of 0.7095$0.7107(n=55)$. Carboniferous-age rocks include limestone, gritstone, and coal measures. The Carboniferous limestone is well defined in terms of biosphere value, giving a plant interquartile range of 0.7090$0.7098(n=22)$. The gritstones that crop out in the Pennines give biosphere values between 0.7107 and $0.7114(\mathrm{n}=11)$; a recent study which determined the bioaccessible $\mathrm{Sr}$ isotope composition from the Millstone Grit gives a value of 0.7115 (Johnson et al., 2019). Clays associated with coal measures give bioavailable values between 0.7095 and $0.7113 \quad(\mathrm{n}=10)$. Taken overall, the predicted range of biosphere values for the lithologies described above would fall predominantly within the range of 0.7087 to 0.7115 (data from Evans et al., 2018).

\section{Materials and Methods}

\section{Sample selection}

As the burial assemblage primarily consists of disarticulated and co-mingled human remains, care had to be taken to avoid possible duplication of results through the inadvertent sampling of mandibular and maxillary teeth that could belong to the same individual. To ensure that all samples originated from discrete individuals, only teeth which remained in situ in mandibles were used for analysis. Loose teeth and teeth from maxillary fragments were not sampled. To avoid the possibility of sampling antimeres, where mandibular dentition was incomplete and fragmentary, only teeth from left-side mandibular fragments were sampled. Teeth in right-side mandibular fragments were not analysed unless the cross-matching left-side fragment of the mandible was present.

Where possible, adjacent permanent molars, which mineralize at different stages of childhood and adolescence, were selected in order to compare isotope ratios within the enamel of teeth that form at successive stages of early life. The development of the crown of the first permanent adult molar tooth commences in utero, just prior to birth, and completes by approximately $4.5 \pm 0.5$ years of age, whilst the second molar crown forms between approximately $2.5 \pm 0.5$ years and $8.5 \pm 0.5$ years of age (AlQahtani et al., 2010; Hillson, 2014: 31, 55-56). The timing of human third permanent molar formation is most variable (Liversidge, 2008: 313): initial cusp formation begins from approximately $8.5 \pm 0.5$ years of age and formation of the crown completes by approximately $14.5 \pm 0.5$ years (AlQahtani et al., 2010). In several cases, sampling of all three of the permanent molars was precluded by ante- or post-mortem tooth loss. In the case of individual 0359/1, all permanent molar teeth on both sides of the mandible had been lost ante-mortem: only one tooth, the right canine, remained in situ in the mandible, which was therefore chosen for sampling: the crown of this tooth begins to form between approximately 10.5 months and $7.5 \pm 0.5$ years of age (AlQahtani et al., 2010).

\section{Aging and sexing}

The approximate age at death of individuals was determined through visual assessment of the stage of tooth eruption 
and root development following AlQahtani et al. (2010). Individuals with fully erupted permanent dentition are denoted as 'adult' in Table 1. Due to disarticulation of skeletal elements within the assemblage in the linear mortuary structure and the inability to associate mandibles with other skeletal elements such as the pelvis, the sex of most of the individuals who were sampled cannot be determined with confidence using conventional osteological methods. Only individual 0957 was found in a fully articulated state and osteological examination by Chamberlain and Witkin (2011: 74-75) suggests this individual was a female who died at approximately $16-17$ years of age (see above).

\section{Methods}

Teeth were processed following procedures developed by Montgomery (2002). Surface enamel was thoroughly abraded using a tungsten carbide dental burr. Enamel chips were then cut using a flexible diamond-edged rotary saw and surfaces again mechanically cleaned using a tungsten carbide dental burr to remove any adhering dentine. An enamel chip of approximately $20-30 \mathrm{mg}$ in weight from each tooth was taken for strontium isotope analysis and another of approximately 10 $\mathrm{mg}$ in weight for oxygen isotope analysis. Dental saws and burrs were cleaned ultrasonically for five minutes and rinsed three times in high purity de-ionized water between preparation of samples.

\section{${ }^{87} \mathrm{Sr} /{ }^{86} \mathrm{Sr}$ analysis}

Samples were transferred in clean sealed containers to the Class 100, HEPAfiltered laboratory facilities at the National Environmental Isotope Facility (NEIF) (Keyworth, Nottingham, England).
Enamel chips were cleaned ultrasonically and rinsed in high purity water (Millipore Alpha Q). They were then dried, weighed into pre-cleaned Teflon beakers, and spiked with a known amount of ${ }^{84} \mathrm{Sr}$ tracer solution to obtain strontium concentrations. Each sample was dissolved in Teflon distilled $8 \mathrm{M} \mathrm{HNO}_{3}$. Samples were converted to chloride using $6 \mathrm{M} \mathrm{HCl}$, taken up in titrated $2.5 \mathrm{M} \mathrm{HCl}$ and pipetted onto ion-exchange chromatography columns. Strontium was separated with Eichrom AG50- X8 resin (200-400 mesh). Procedural blanks were below 80 pg. Samples were loaded on to Re filaments using a method adapted from Birck (1986). Strontium isotope composition and concentrations were then determined by Thermal Ionization Mass Spectrometry using a ThermoTriton automated multicollector mass spectrometer. To correct for fractionation during the process of mass spectrometry, ${ }^{87} \mathrm{Sr} /{ }^{86} \mathrm{Sr}$ values are normalized to the accepted value for ${ }^{88} \mathrm{Sr} /{ }^{86} \mathrm{Sr}=$ 0.1194. During the period of this study, the machine gave a value for the international standard for ${ }^{87} \mathrm{Sr} /{ }^{86} \mathrm{Sr}$ (NBS 987) of $0.710253 \pm 0.000012(2 \sigma, n=350)$. An estimate of the reproducibility of strontium concentration ( $\mathrm{Sr} \mathrm{ppm}$ ) is provided by replicate analysis of an aliquot of bone standard solution (NIST1486), which gave $7.22 \pm 0.27 \mathrm{ppm}( \pm 3.75 \%, 1 \sigma, \mathrm{n}=16)$.

\section{$\delta^{18} \mathrm{O}$ and $\delta^{13} \mathrm{C}$ analysis}

Initial preparation of core enamel chips for $\delta^{18} \mathrm{O}$ and $\delta^{13} \mathrm{C}$ analysis was undertaken using the same methods employed above for strontium isotope analysis. Samples were then transferred as clean core enamel chips to the NEIF, where they were powdered. Oxygen $\left(\delta^{18} \mathrm{O}_{\text {carbonate }}\right)$ and carbon $\left(\delta^{13} \mathrm{C}_{\text {carbonate }}\right)$ isotope ratios in the carbonate fraction of enamel were determined using approximately $3 \mathrm{mg}$ of clean 
powdered enamel following the method outlined in Chenery et al. (2010). Isotope ratios are reported as delta $(\delta)$ values, in parts per thousand (per mil; \%0) normalized to the VPDB scale using an in-house carbonate reference material, Keyworth Carrera Marble (KCM), which is calibrated against NBS19 certified reference material. Analytical reproducibility for this run of $\mathrm{KCM}$ was $\pm 0.09 \%$ o $(1 \sigma, \mathrm{n}=14)$ for $\delta^{18} \mathrm{O}$ and for $\delta^{13} \mathrm{C} \pm 0.04 \%$ o $(1 \sigma, \mathrm{n}=14)$. $\delta^{18} \mathrm{O}_{\text {carbonate }}$ values were normalized to the VSMOW scale using the equation of Coplen et al. (1988) (VSMOW = $1.03091 \times \delta^{18} \mathrm{O}$ VPDB +30.91$)$. Conversion between $\delta^{18} \mathrm{O}_{\text {carbonate }}$ to $\delta^{18} \mathrm{O}_{\text {phosphate }}$ was then undertaken using the regression equation of Chenery et al. (2010) $\left(\delta^{18} \mathrm{O}_{\text {phosphate }}\right.$ $\left.=1.0322 \times \delta^{18} \mathrm{O}_{\text {carbonate }}-9.6849\right)$. The uncertainty involved in calculating $\delta^{18} \mathrm{O}_{\text {phosphate }}$ is considered to be low $(0.28 \% 0,1 \sigma$, Chenery et al., 2010). All data are presented in Table 1.

\section{Oxygen Isotope Results}

Values of $\delta^{18} \mathrm{O}_{\text {carbonate }}$ (VSMOW) of enamel from second and third permanent molars with strontium isotope ratios give a mean of $26.8 \pm 0.3 \% 0,1 \sigma(n=13)$. First molar teeth were excluded from this calculation, since, with deciduous teeth, formation of the first molar crown begins in utero and continues during the months following birth and values may therefore be influenced by consumption of breast milk (Roberts et al., 1988: 625; Wright \& Schwarcz, 1998: 14; AlQahtani et al., 2010; Hillson, 2014: 31, 55-56; Britton et al., 2015: 8). However, at Whitwell the incorporation of $\delta^{18} \mathrm{O}_{\text {carbonateVSMOW }}$ values of enamel from first molars does not change the mean value and only increases the uncertainty slightly to $26.8 \pm$ $0.4 \% 0 \quad(1 \sigma, \mathrm{n}=21)$. If converted to $\delta^{18} \mathrm{O}_{\text {phosphateVsMOW }}$ the full data set $(\mathrm{n}=$ 21) gives $18.0 \pm 0.4 \% 0,1 \sigma$.

Oxygen isotope ratios recorded in enamel at Whitwell are comparable to those found within human archaeological populations buried in temperate regions of mainland Europe (Lightfoot \& O'Connell, 2016). Values of $\delta^{18} \mathrm{O}_{\text {phosphate }}$ exhibited by archaeological populations buried in Britain may overlap with those found on the adjacent near continent due to climatic similarities. That precludes distinguishing between these two areas using oxygen isotope analysis alone (Lightfoot \& O'Connell, 2016; e.g. Brettell et al., 2012a: 127; Evans et al., 2012). Such values could link these individuals either to a climate zone consistent with that of Britain, or to areas of the European mainland with similar rainwater/ drinking water compositions. Recent evidence suggests that oxygen isotope ratios in human tooth enamel may also be influenced by culturally mediated behaviour, such as boiling drinking water, brewing, and stewing food (Brettell et al., 2012b). The values found at Whitwell do, however, contrast with oxygen isotope ratios found amongst human burial populations associated with regions of cooler climate in Europe (e.g. Scandinavia: Montgomery et al., 2014; Chenery et al., 2014; Price \& Naumann, 2015; or the Alps: Müller et al., 2003), where much lower values can be recorded $\left(\delta^{18} \mathrm{O}_{\text {carbonate }}\right.$ below approximately $24.5 \% 0$ or $\delta^{18} \mathrm{O}_{\text {phosphate }}$ below approximately $15.5 \%$ ).

\section{Strontium Isotope Results}

The strontium isotope results are presented in Figure 2, which shows the $\mathrm{Sr}$ concentrations versus ${ }^{87} \mathrm{Sr} /{ }^{86} \mathrm{Sr}$ results for tooth enamel. The data can be divided roughly into two groups. The majority of individuals (0219, 0334, 0451, 0487, 0543) have low Sr concentrations, between 


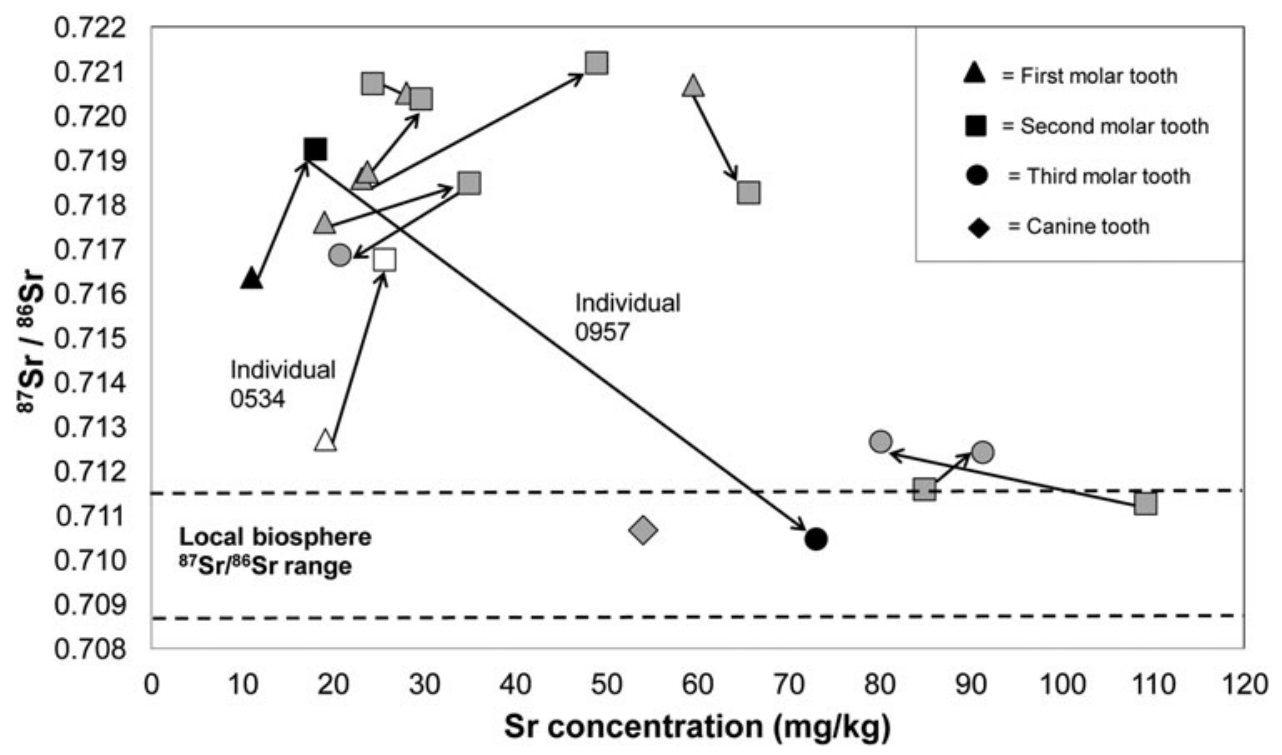

Figure 2. ${ }^{87} \mathrm{Sr}{ }^{86} \mathrm{Sr}$ isotope composition plotted against Sr concentration ( $p$ pm) for buman tooth enamel samples from the Whitwell cairn. Arrows link samples from teeth belonging to the same individual, denoting the direction of change in isotope ratio and concentration between earlier and later forming teeth. Individuals who exhibit large shifts in ${ }^{87} \mathrm{Sr}^{86} \mathrm{Sr}$ values between teeth are highlighted in black and white. A dashed line denotes the bioavailable ${ }^{87} \mathrm{Sr}{ }^{86} \mathrm{Sr}$ range on lithologies in the immediate area around the Whitwell cairn.

11 and $66 \mathrm{ppm}$, and high ${ }^{87} \mathrm{Sr} /{ }^{86} \mathrm{Sr}$ ratios $>0.7164$. In contrast, three individuals (0420/1, 0359/1, 0512/2) have relatively low ${ }^{87} \mathrm{Sr} /{ }^{86} \mathrm{Sr}$ values, between 0.710 and 0.712 , and have Sr concentrations ranging between 54 and 109 ppm. The remains of the latter two individuals (0359/1, 0512/2) were recovered from above the limestone slabs in the linear mortuary enclosure and are attributed to the secondary phase of use of this structure for burial (phase 4/B); whilst the remains of individual $0420 / 2$ were not securely associated with a specific stratigraphic context within the linear mortuary enclosure and could therefore be associated with either the earliest or with a later phase of its use.

The contrasting strontium isotope values exhibited by these two groups could indicate that childhood dietary resources had been derived from two contrasting terrains. Two individuals (0534 and 0957) have values that bridge the gap between the isotope compositions of the two groups, with the latter, 0957, also showing a significant change in $\mathrm{Sr}$ concentration between teeth. The dentition from individual 0534 (highlighted in white in Figure 2) was located below the limestone slabs in the linear mortuary structure and is therefore associated with the first phase of burial activity at this structure. Individual 0957 (highlighted in black in Figure 2) is the female burial from the oval cairn next to the linear burial structure within the monument. The shift in values between adjacent teeth exhibited by these individuals, 0534 and 0957 , could be interpreted as indicative of movement during childhood between the two terrains (Figure 2).

Some constraints can be placed on these two childhood domains. The high strontium isotope ratios and low $\mathrm{Sr}$ 
concentrations that the majority of the individuals exhibit are typical of areas of ancient rock or very radiogenic rock such as granite. Thus far, such values have been recorded in human teeth from areas where such rocks crop out, in regions such as Sweden (Sjogren et al., 2009), India (Valentine et al., 2015), South Africa (Copeland et al., 2008), and Portugal (Waterman et al., 2014). Plant samples collected in the Black Forest of south-western Germany (Bentley \& Knipper, 2005; Bentley, 2006: 145; Oelze et al., 2012) and on the Massif Central and Armorican Massif in France have also given these values (Négrel \& Pauwels, 2004; Willmes et al., 2013, 2018). British bioavailable values higher than 0.717 have been recorded in plant samples taken on granites in Dartmoor in the south-west of England (Gundula Müldner, pers. comm.) and in Scotland, for example in regions of the Scottish Highlands such as the Cairngorm Mountains (Evans et al., 2010, 2018).

The lower range of values from 0.710 to 0.7127 are well within the range of Sr biosphere values found in Britain. Values around 0.710 are fully consistent with the area of the Whitwell cairn, although values above 0.7116 are harder to reconcile with the bioavailable range within the immediate vicinity of the site. Individuals with values between 0.710 to 0.7127 could therefore have sourced their childhood diet locally within Britain; however, this range of strontium values is also very common on the European mainland (Willmes et al., 2013; Bataille et al., 2018).

\section{Discussion}

The ${ }^{87} \mathrm{Sr} /{ }^{86} \mathrm{Sr}$ vs $\delta^{18} \mathrm{O}_{\text {carbonateVsMow for }}$ the Whitwell individuals is presented along with published data from other British earlier Neolithic populations, from Hazleton North (Gloucestershire, England), Hambledon Hill
(Dorset, England), and Ty Isaf and Penywyrlod (Powys, Wales) (Figure 3). The majority of individuals at these sites have strontium isotope ratios that fall within the appropriate biosphere range for their region. This suggests that most of these individuals could have obtained their childhood diet locally within Britain (see Neil et al., 2016, 2017). In contrast, the majority of individuals sampled from the Whitwell cairn, and one individual from the Neolithic Penywyrlod long cairn (Neil et al., 2017) have ${ }^{87} \mathrm{Sr} /{ }^{86} \mathrm{Sr}$ values that are greater than 0.7170 , which, according to present understanding of the methodology employed, suggests they obtained their dietary resources a significant distance from the regions in which they were buried.

In considering where values higher than 0.7170 may originate, we are restricted by the amount and extent of current biosphere reference data, and so any assessment must be considered within the context of this constraint. As noted above, Dartmoor in south-west England and Scotland are among the possible source areas, but both are more than $300 \mathrm{~km}$ from Whitwell. Furthermore, in neither region does the appearance of Neolithic features significantly pre-date the Whitwell burials: current modelling of radiocarbon dates suggests that Neolithic material culture and practices began to appear in south-western England and Scotland in the decades around $3800 \mathrm{cal}$ BC (Bayliss et al., 2011: 736, 822-24, 835-40). Bayesian modelling indicates that Neolithic practices appeared within the English Midlands, the region surrounding Whitwell, from the thirty-ninth century cal $\mathrm{BC}$ to the thirty-seventh century cal BC (Bayliss et al., 2011: 833; Griffiths, 2011: 299-300). This suggests the Neolithic way of life may have only recently become established in central England at the time the Whitwell cairn 


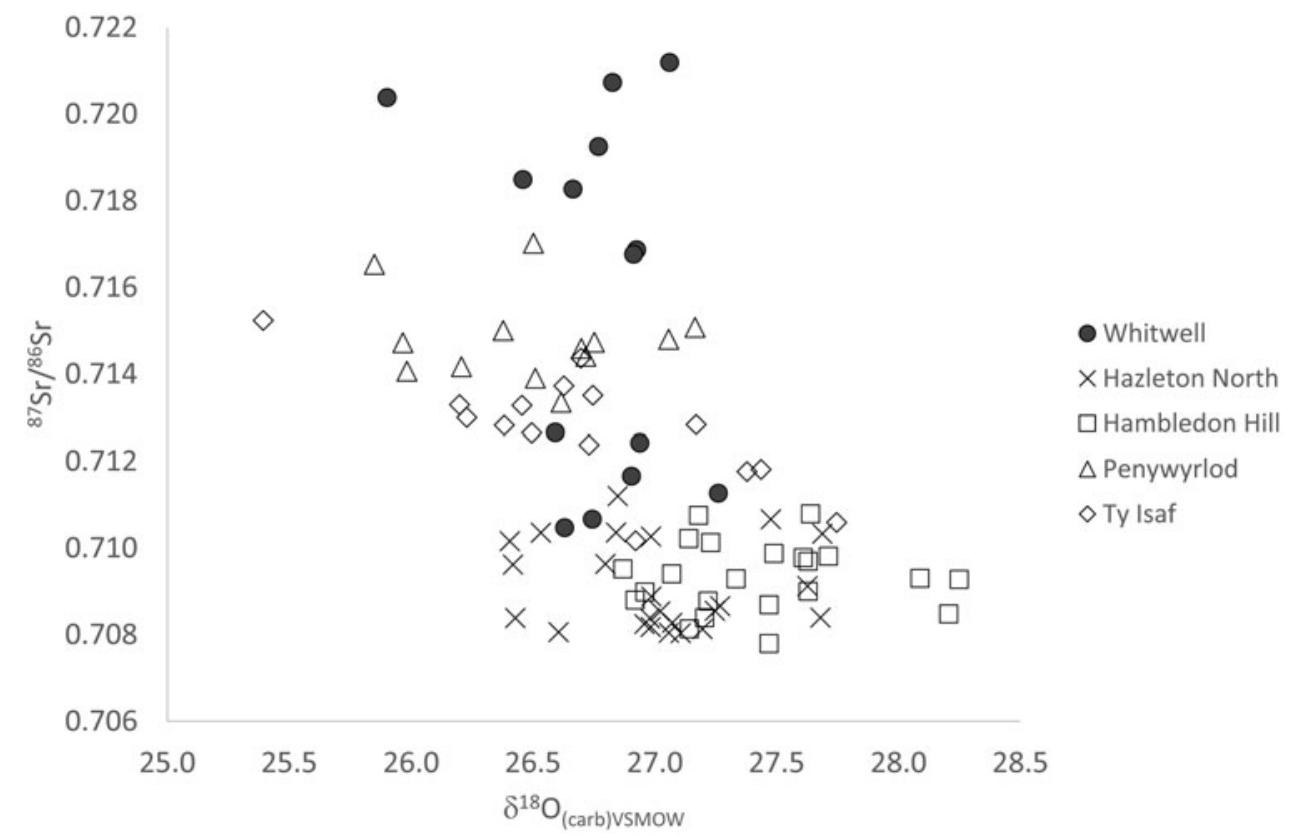

Figure 3. ${ }^{87} \mathrm{Sr}{ }^{86} \mathrm{Sr}$ vs $\delta^{18} \mathrm{O}_{\text {carbonateVSMOW }}$ comparison of dentition from earlier Neolithic sites at Hazleton North (Gloucestershire, England, Neil et al., 2016), Hambledon Hill (Dorset, England, Neil et al., 2018), Ty Isaf and Penywyrlod (Powys, Wales, Neil et al., 2017), and Whitwell (Derbyshire, England).

was first used for burial (beginning at 3780-3700 cal BC 95 per cent probability; Griffiths, 2011: 85, see above). Ireland does not presently seem to be a possible place of origin from the currently available biosphere data (Snoeck et al., 2016, 2020). Values above 0.7170 have been recorded in Norway and Sweden (e.g. Price et al., 2015: 112), the Alps (Müller et al., 2003), Portugal (Waterman et al., 2014), the Massif Central in France (Willmes et al., 2013, 2018), and the Black Forest of south-western Germany (Bentley \& Knipper, 2005; Bentley, 2006: 145; Oelze et al., 2012). Most of Scandinavia, however, and possibly Portugal, may be excluded on the basis of the oxygen isotope composition and, furthermore, none of these regions have Neolithic material culture similar to that found in Britain during the early fourth millennium $\mathrm{BC}$.
Biosphere ${ }^{87} \mathrm{Sr} /{ }^{86} \mathrm{Sr}$ values within the range exhibited by those buried at Whitwell have also been recorded in plants growing on the Armorican Massif within Lower Normandy and Brittany, in north-western France (Négrel \& Pauwels, 2004; Willmes et al., 2013, 2018). Neolithic material culture comparable to that found in Britain is present in this region (Pioffet, 2015). Similarities in material culture indicate that this was one of the areas of the European mainland from which Neolithic material culture and practices were introduced to Britain (e.g. Sheridan, 2010a, 2010b; Rowley-Conwy, 2011; Anderson-Wymark \& Garrow, 2015: 74; Pioffet, 2015).

Radiocarbon dating evidence suggests that development of farming in Britain was an asynchronous process, beginning during the first few centuries of the fourth millennium $\mathrm{BC}$, with variation in both the 
regional timing and tempo of establishment of the Neolithic across Britain (Bayliss et al., 2011; Whittle et al., 2011; Griffiths, 2011). Both the asynchronous nature of the establishment of new cultural traditions and recent study of Early Neolithic material culture found within Britain indicate that mobility patterns during the first few centuries of the fourth millennium BC were likely to have been complex. The analysis of material culture shows that Britain was linked to at least two different regions of the European mainland during the first few centuries of the fourth millennium $\mathrm{BC}$, with mobility from both the Picardie/Pas de Calais area of northern France to the eastern seaboard of Britain at approximately $4000 \mathrm{BC}$, as well as from Brittany and Lower Normandy to south-western Britain from approximately 3800 BC (Pioffet, 2015; see also Sheridan, 2010a, 2010b). As biosphere ${ }^{87} \mathrm{Sr} /{ }^{86} \mathrm{Sr}$ values comparable to those found in enamel at Whitwell have been recorded in Lower Normandy and Brittany (Négrel \& Pauwels, 2004; Willmes et al., 2013, 2018), the results could perhaps be interpreted to support archaeological arguments for mobility between these areas of the European mainland and Britain during the early fourth millennium BC.

The precise nature of that mobility remains to be established. Reiter and Frei (2019: 457) have recently proposed a fourpart model for human mobility patterns in prehistory: 1) non-migratory; 2) point-topoint migratory; 3) back-and-forth; and 4) repeated mobility, subdivided into $4 \mathrm{a}$ (cyclical mobility) and 4b (non-cyclical mobility). There is also evidence supporting larger-scale movements of people into new areas. Recent aDNA analysis, drawn from a sample of six Mesolithic and sixty-seven Neolithic individuals from England, Wales and Scotland, proposed that the Neolithic transition in Britain could be attributed predominantly to the immigration of farmers from mainland Europe, with relatively little contribution from preexisting Mesolithic populations (Brace et al., 2019). Domestic plants and animals too must have been brought from the European mainland, and material culture (ceramics, polished stone, funerary monumentality) also shows strong European connections (e.g. Pioffet, 2015; Scarre, 2015; Walker, 2018). Taken together with the aDNA evidence, this suggests that entire communities may have moved from mainland Europe during this period. That could fall within the category of point-topoint mobility, although the process was at a larger than individual scale. There is evidence of specific artefacts such as axeheads of Alpine jadeitite and Plussulien (Brittany) dolerite entering Britain at the same period; although the latter are relatively few in number and restricted to southern England, whereas the former spread northwards into Scotland (Sheridan et al., 2011, 2012; Walker, 2018). There is also a chronological distinction, the jadeitite axeheads being brought, perhaps as heirlooms, by Early Neolithic farmers (assuming they were not already circulating among the Late Mesolithic communities of Britain: Thomas, 2013: 280-83), whereas the Plussulien quarries may have been in active use during the earlier and middle centuries of the fourth millennium, and may indicate ongoing movement from France to Britain after the initial farming migration (Bayliss et al., 2011: 797-800). By contrast, there is very little evidence for movement in the contrary direction, from Britain to northern France, although some degree of back-and-forth mobility cannot be excluded.

Recent application of stable isotope analysis has provided evidence for movement at an individual level and has begun to elucidate patterns of mobility during the early centuries of the fourth millennium 
BC (Neil et al., 2016, 2017, 2018). Thus far, it is individuals buried in monuments that were in use in Britain from the thirty-eighth century BC who have been found to have the highest ${ }^{87} \mathrm{Sr} /{ }^{86} \mathrm{Sr}$ values. Individuals from the sites of Whitwell and Penywyrlod in Wales (which radiocarbon models suggest may have both been in use from the thirty-eighth century BC; Neil et al., 2017; Whittle, pers. comm.) have values consistent with mobility over long distances (greater than $300 \mathrm{~km}$ ) during their lifetimes.

The young woman buried at Whitwell, individual 0957, who died between 3770 and $3670 \mathrm{cal} \mathrm{BC}$ (95 per cent probability, Griffiths, 2011: 85), perhaps provides a good example of point-to-point migratory mobility (after the model proposed by Reiter \& Frei, 2019). This individual was buried in the oval cairn adjacent to the linear mortuary structure (Figure 1) under the long mound at Whitwell. She exhibits a very large shift in ${ }^{87} \mathrm{Sr} /{ }^{86} \mathrm{Sr}$ values between her second and third molar teeth, from a value of 0.7192 to 0.7105 (highlighted in black in Figure 2). The strontium isotope ratio of enamel from her third molar is comparable to the local ${ }^{87} \mathrm{Sr} /{ }^{86} \mathrm{Sr}$ range in the area around Whitwell. The large change in values this individual exhibits between these two teeth could suggest that she moved a significant distance at approximately eight to nine years of age, around the time her third molar tooth began to form. She died shortly after the formation of her third molar was complete, at approximately sixteen to seventeen years of age (Chamberlain and Witkin, 2011: 7475).

In contrast to Whitwell and Penywyrlod, all individuals sampled from sites that radiocarbon models suggest were in use from the thirty-seventh century onward, such as Hazleton North (Gloucestershire, England), Hambledon Hill (Dorset, England), and Ty Isaf (Powys,
Wales), have lower ${ }^{87} \mathrm{Sr} /{ }^{86} \mathrm{Sr}$ values, consistent with those that are more locally bioavailable. The site of Hazleton North, which modelling suggests was used for burial from the thirty-seventh century, may provide an example of repeated cyclical mobility (as defined by Reiter \& Frei, 2019; see Meadows et al., 2007; Neil et al., 2016). Here, ${ }^{87} \mathrm{Sr} /{ }^{86} \mathrm{Sr}$ values could be interpreted as being indicative of a routine of mobility between two different locations followed by short stays, perhaps suggesting transhumance (see Neil et al., 2016).

Recent data has, therefore, begun to provide an insight into differing patterns of mobility during the fourth millennium BC. However, in modelling mobility patterns during this period, it should be remembered that in Britain the number of sites so far sampled for ${ }^{87} \mathrm{Sr} /{ }^{86} \mathrm{Sr}$ analysis still remains small. More detailed modelling of population mobility patterns, including variation in mobility patterns over time through the fourth millennium $\mathrm{BC}$, may become possible with the production of further data.

\section{Conclusion}

The majority of the individuals buried in the Whitwell cairn have strontium isotope ratios higher than 0.7170 . High values are rare in human enamel in burials found in Britain (Evans et al., 2012), and all current evidence suggests that such values do not originate from the biosphere of central England (Evans et al., 2018). Based on present understanding of the methodology employed and the way in which strontium isotope ratios within human enamel are derived, the results suggest that these individuals obtained the majority of their dietary resources from a geographical area in which high ${ }^{87} \mathrm{Sr} /{ }^{86} \mathrm{Sr}$ values are routinely bioavailable: for 
example, on granite or ancient basement gneisses. British bioavailable values higher than 0.7170 have been recorded in plants growing in Scotland and on granites in Dartmoor in south-west England. In these regions, however, the appearance of Neolithic features does not significantly pre-date the Whitwell burials: current modelling of radiocarbon dates suggests that Neolithic material culture and practices only began to appear in southwestern England and Scotland in the decades around $3800 \mathrm{cal} \mathrm{BC}$ (Bayliss et al., 2011: 736, 822-24, 835-40). Strontium isotope ratios higher than 0.7170 , comparable to those exhibited by the group at Whitwell, have been recorded in the biosphere on the Armorican Massif in northwestern France (Négrel \& Pauwels, 2004; Willmes et al., 2013, 2018). Recent analysis of Early Neolithic material culture found within Britain has been used to argue that there may have been population mobility between this area and Britain from approximately $3800 \mathrm{cal} \mathrm{BC}$ (Pioffet, 2015; see also Sheridan, 2010a, 2010b). Strontium isotope analysis cannot, on its own, determine the geographical source of the ${ }^{87} \mathrm{Sr} /{ }^{86} \mathrm{Sr}$ values found within human enamel at Whitwell: competing arguments for links to different source areas must, therefore, be evaluated on the basis of present archaeological and radiocarbon dating evidence. Based on current understanding of British biosphere ${ }^{87} \mathrm{Sr} /{ }^{86} \mathrm{Sr}$ data, the results do, however, provide evidence for individual human mobility over long distances during the thirty-eighth century BC, a period associated with the rapid spread of new cultural practices across Britain (Bayliss et al., 2011: 801).

\section{Acknowledgements And Authorship}

Samantha Neil and Jane Evans undertook the analysis; Samantha Neil wrote the article with contributions from Chris Scarre; all authors discussed drafts of the manuscript. Samantha Neil was funded through a Durham University Doctoral Studentship award; the strontium and oxygen isotope analysis was funded through NIGFSC grant IP-1290-0512 awarded to Janet Montgomery. Samantha Neil designed the research. The results of analysis are available in Table 1 here. We would like to thank Gundula Müldner for discussion of British ${ }^{87} \mathrm{Sr} /{ }^{86} \mathrm{Sr}$ biosphere data. We would also like to thank Hilary Sloane (National Environmental Isotope Facility) for analytical support, Andrew Chamberlain, Blaise Vyner, Ian Wall, Maria Smith, and Creswell Crags Museum for access to collections and for permission to undertake sampling.

\section{REFERENCES}

AlQahtani, S.J., Hector, M.P. \& Liversidge, H.M. 2010. Brief Communication: The London Atlas of Human Tooth Development and Eruption. American Journal of Physical Anthropology, 142: 48190. https://doi.org/10.1002/ajpa.21258

Anderson-Whymark, H. \& Garrow, D. 2015. Seaways and Shared Ways: Imaging and Imagining the Movement of People, Objects and Ideas over the Course of the Mesolithic-Neolithic Transition, c. 50003500 BC. In: H. Anderson-Whymark, D. Garrow \& F. Sturt, eds. Continental Connections: Exploring Cross-Channel Relationships from the Lower Palaeolithic to the Iron Age. Oxford: Oxbow, pp. 59-77.

Bataille, C.P., von Holstein, I.C.C., Laffoon, J.E., Willmes, M., Liu, X.M. \& Davies, G.R. 2018. A Bioavailable Strontium Isoscape for Western Europe: A Machine Learning Approach. Plos One, 13: e0197386. https://doi.org/10.1371/journal. pone.0197386

Bayliss, A., Healy, F., Whittle, A.W.R. \& Cooney, G. 2011. Neolithic Narratives: British and Irish Enclosures in their Timescapes. In: A.W.R. Whittle, F. Healy \& A. Bayliss, eds. Gathering Time: 
Dating the Early Neolithic Enclosures of Southern Britain and Ireland. Oxford: Oxbow, pp. 682-847.

Bentley, R.A. 2006. Strontium Isotopes from the Earth to the Archaeological Skeleton: A Review. Journal of Archaeological Method and Theory, 13: 135-87. https://doi.org/10. 1007/s10816-006-9009-x

Bentley, R.A. \& Knipper, C. 2005. Geographical Patterns in Biologically Available Strontium, Carbon and Oxygen Isotope Signatures in Prehistoric SouthWest Germany. Archaeometry, 47: 629-44. https://doi.org/10.1111/j.1475-4754.2005. 00223.x

Birck, J.L. 1986. Precision K-Rb-Sr Isotopic Analysis: Application to $\mathrm{Rb}-\mathrm{Sr}$ Chronology. Chemical Geology, 56(1-2): 73-83.

Brace, S., Diekmann, Y., Booth, T.J., van Dorp, L., Faltyskova, Z., Rohland, N., et al. 2019. Ancient Genomes Indicate Population Replacement in Early Neolithic Britain. Nature Ecology $\mathcal{E}^{\circ}$ Evolution, 3: 765-71. https://doi.org/10. 1038/s41559-019-0871-9

Bradley, R., Haselgrove, C. \& Webley, L. 2015. The Later Prehistory of North-West Europe: The Evidence of Development-led Fieldwork. Oxford: Oxford University Press.

Brettell, R., Evans, J.A., Marzinzik, S., Lamb, A. \& Montgomery, J. 2012a. 'Impious Easterners': Can Oxygen and Strontium Isotopes Serve as Indicators of Provenance in Early Medieval European Cemetery Populations? European Journal of Archaeology, 15: 117-45. https://doi.org/ 10.1179/1461957112Y.0000000001

Brettell, R., Montgomery, J. \& Evans, J. 2012b. Brewing and Stewing: The Effect of Culturally Mediated Behaviour on the Oxygen Isotope Composition of Ingested Fluids and the Implications for Human Provenance Studies. Journal of Analytical Atomic Spectrometry, 27: 778-85. https:// doi.org/10.1039/C2JA10335D

Britton, K., Fuller, B.T., Tütken, T., Mays, S. \& Richards, M.P. 2015. Oxygen Isotope Analysis of Human Bone Phosphate Evidences Weaning Age in Archaeological Populations. American Journal of Physical Anthropology, 157: 226-41. https://doi.org/ 10.1002/ajpa.22704

Chamberlain, A. \& Witkin, A. 2011. The Human Remains. In: B. Vyner \& I. Wall, eds. A Neolithic Cairn at Whitwell, Derbyshire. Derbyshire Archaeological Journal, 131: 71-93.

Chenery, C.A., Evans, J.A., Score, D., Boyle, A. \& Chenery, S.R. 2014. A Boat Load of Vikings? Journal of the North Atlantic, 7: 4353. https://doi.org/10.3721/037.002.sp704

Chenery, C.A., Müldner, G., Evans, J., Eckardt, H. \& Lewis, M. 2010. Strontium and Stable Isotope Evidence for Diet and Mobility in Roman Gloucester, UK. Journal of Archaeological Science, 37: 150-63. https://doi.org/10.1016/j.jas.2009. 09.025

Copeland, S.R., Sponheimer, M., le Roux, P.J., Grimes, V., Lee-Thorp, J.A., de Ruiter, D.J. \& Richards, M.P. 2008. Strontium Isotope Ratios (Sr-87/Sr-86) of Tooth Enamel: A Comparison of Solution and Laser Ablation Multicollector Inductively Coupled Plasma Mass Spectrometry Methods. Rapid Communications in Mass Spectrometry, 22: 3187-94. https://doi.org/ $10.1002 / \mathrm{rcm} .3717$

Coplen, T.B. 1988. Normalization of Oxygen and Hydrogen Isotope Data. Chemical Geology, 72: 293-97. https://doi.org/10. 1016/0168-9622(88)90042-5

Evans, J.A., Chenery, C.A., Mee, K., Cartwright, C.E., Lee, K.A., Marchant, A.P. \& Hannaford, L. 2018. Biosphere Isotope Domains GB (V1): Interactive Website, British Geological Survey [online interactive resource] [accessed 7 October 2019]. Available at: <https://doi.org/10.5285/ 3b141dce-76fc-4c54-96fa-c232e98010ea>

Evans, J.A., Chenery, C.A. \& Montgomery, J. 2012. A Summary of Strontium and Oxygen Isotope Variation in Archaeological Human Tooth Enamel Excavated from Britain. Journal of Analytical Atomic Spectrometry, 27: 754-64. https://doi.org/ 10.1039/C2JA10362A

Evans, J.A., Montgomery, J., Wildman, G. \& Boulton, N. 2010. Spatial Variations in Biosphere ${ }^{87} \mathrm{Sr} /{ }^{86} \mathrm{Sr}$ in Britain. Journal of the Geological Society, 167: 1-4. https://doi. org/10.1144/0016-76492009-090

Griffiths, S. 2011. Chronological Modelling of the Mesolithic-Neolithic Transition in the Midlands and North of England (unpublished $\mathrm{PhD}$ dissertation, Cardiff University).

Hillson, S. 2014. Tooth Development in Human Evolution and Bioarchaeology. Cambridge: Cambridge University Press. 
Hofmanová, Z., Kreutzer, S., Hellenthal, G., Sell, C., Diekmann, Y., Díez-del-Molino, D., et al. 2016. Early Farmers from Across Europe Directly Descended from Neolithic Aegeans. Proceedings of the National Academy of Sciences, 113: 6886-91. https:// doi.org/10.1073/pnas.1523951113

Johnson, L., Montgomery, J., Evans, J. \& Hamilton, E. 2019. Contribution of Strontium to the Human Diet from Querns and Millstones: An Experiment in Digestive Sr- Isotope Uptake. Archaeometry, 61: 1366-81. https://doi.org/ 10.1111/arcm. 12485

Lightfoot, E. \& O'Connell, T.C. 2016. On the Use of Biomineral Oxygen Isotope Data to Identify Human Migrants in the Archaeological Record: Intra-Sample Variation, Statistical Methods and Geographical Considerations. PLOS ONE, 11: e0153850. https://doi.org/10.1371/ journal.pone. 0153850

Liversidge, H.M. 2008. Timing of Human Mandibular Third Molar Formation. Annals of Human Biology, 35: 294-321. https://doi.org/10.1080/ 03014460801971445

Meadows, J., Barclay, A. \& Bayliss, A. 2007. A Short Passage of Time: The Dating of the Hazleton Long Cairn Revisited. Cambridge Archaeological Journal, 17: 45-64. https://doi. org/10.1017/S0959774307000169

Montgomery, J. 2002. Lead and Strontium Isotope Compositions of Human Dental Tissues as an Indicator of Ancient Exposure and Population Dynamics (unpublished $\mathrm{PhD}$ dissertation: University of Bradford, UK).

Montgomery, J., Grimes, V., Buckberry, J., Evans, J.A., Richards, M.P. \& Barrett, J. H. 2014. Finding Vikings with Isotope Analysis: The View from Wet and Windy Islands. Journal of the North Atlantic, 7: 54-70. https://doi.org/10.3721/037.002. sp705

Müller, W., Fricke, F., Halliday, A.N., McCulloch, M.T. \& Wartho, J.-A. 2003. Origin and Migration of the Alpine Iceman. Science, 302: 862-66. https://doi. org/10.1126/science.1089837

Négrel, P. \& Pauwels, H. 2004. Interaction between Different Groundwaters in Brittany Catchments (France): Characterizing Multiple Sources through Strontium and Sulphur Isotope Tracing. Water, Air, and
Soil Pollution, 151: 261-85. https://doi.org/ 10.1023/B:WATE.0000009912.04798.b7

Neil, S., Evans, J., Montgomery, J. \& Scarre, C. 2016. Isotopic Evidence for Residential Mobility of Farming Communities During the Transition to Agriculture in Britain. Royal Society Open Science, 3: 150522. https://doi.org/10.1098/rsos.150522

Neil, S., Evans, J., Montgomery, J. \& Scarre, C. 2018. Isotopic Evidence for Landscape Use and the Role of Causewayed Enclosures During the Earlier Neolithic in Southern Britain. Proceedings of the Prehistoric Society, 84: 185-205. https:// doi.org/10.1017/ppr.2018.6

Neil, S., Montgomery, J., Evans, J., Cook, G. T. \& Scarre, C. 2017. Land Use and Mobility During the Neolithic in Wales Explored Using Isotope Analysis of Tooth Enamel. American Journal of Physical Anthropology, 164: 371-93. https://doi.org/ 10.1002/ajpa.23279

Oelze, V.M., Nehlich, O. \& Richards, M.P. 2012. 'There's No Place Like Home': No Isotopic Evidence for Mobility at the Early Bronze Age Cemetery of Singen, Germany. Archaeometry, 54: 752-78. https://doi.org/10.1111/j.1475-4754.2011. 00644.x

Pioffet, H. 2015. Sociétés et identités du premier Néolithique de Grande-Bretagne et d'Irlande dans leur contexte ouest européen : caractérisation et analyses comparatives des productions céramiques entre Manche, Mer d'Irlande et Mer du Nord (unpublished $\mathrm{PhD}$ dissertation: Durham University and Université de Rennes 1).

Price, T.D., Frei, K.M. \& Naumann, E. 2015. Isotopic Baselines in the North Atlantic Region. Journal of the North Atlantic, 7: 103-36. https://doi.org/10.3721/037.002. sp707

Price, T.D. \& Naumann, E. 2015. The Peopling of the North Atlantic: Isotopic Results from Norway. Journal of the North Atlantic, 7: 88-102. https://doi.org/10. 3721/037.002.sp706

Reiter, S.S. \& Frei, K.M. 2019. Interpreting Past Human Mobility Patterns: A Model. European Journal of Archaeology, 22: 45469. https://doi.org/10.1017/eaa.2019.35

Roberts, S.B., Coward, W.A., Ewing, G., Savage, J., Cole, T.J. \& Lucas, A. 1988. Effect of Weaning on Accuracy of Doubly Labelled Water Method in Infants. 
American Journal of Physiology: Regulatory, Integrative and Comparative Physiology, 254: R622-27. https://doi.org/10.1152/ ajpregu.1988.254.4.R622

Rowley-Conwy, P. 2011. Westward Ho! The Spread of Agriculture from Central Europe to the Atlantic. Current Anthropology, 52: S431-51. https://doi.org/ 10.1086/658368

Scarre, C. 2015. Parallel Lives? Neolithic Funerary Monuments and the Channel Divide. In: H. Anderson-Whymark, D. Garrow \& F. Sturt, eds. Continental Connections: Exploring Cross-Channel Relationships from the Lower Palaeolithic to the Iron Age. Oxford: Oxbow, pp. 78-98.

Sheridan, J.A. 2010a. The Neolithisation of Britain and Ireland: The Big Picture. In: B. Finlayson \& G. Warren, eds. Landscapes in Transition. Oxford: Oxbow, pp. 89-105.

Sheridan, J.A. 2010b. The Earliest Pottery in Britain and Ireland and its Continental Background. In: B. Vanmontfort, L.P. Louwe Kooijmans, L. Amkreutz \& L. Verhart, eds. Pots, Farmers and Foragers: Pottery Traditions and Social Interaction in the Earliest Neolitbic of the Lower Rhine Area. Leiden: Leiden University. pp. 189-207.

Sheridan, A. \& Pailler, Y. 2012. Les haches alpines et leurs imitations en GrandeBretagne, dans l'île de Man, en Irlande et dans les îles Anglo-Normandes. In P. Pétrequin, S. Cassen, M. Errera, L. Klassen, A. Sheridan \& A.-M. Pétrequin, eds. Jade. Grandes haches alpines du Néolithique européen. Ve et IVe millénaires av. J.-C. Besançon: Presses Universitaires de Franche-Comté, pp. 1046-87.

Sheridan, A., Pailler, Y., Pétrequin P. \& Errera, M. 2011. Old Friends, New Friends, a Long-lost Friend and False Friends: Tales from Projet JADE In: V. Davis \& M. Edmonds, eds. Stone Axe Studies III. Oxford: Oxbow Books, pp. 411-26.

Sjogren, K.G., Price, T.D. \& Ahlstrom, T. 2009. Megaliths and Mobility in SouthWestern Sweden: Investigating Relationships between a Local Society and its Neighbours Using Strontium Isotopes. Journal of Anthropological Archaeology, 28: 85-101.

Snoeck, C., Pouncett, J., Ramsey, G., Meighan, I.G., Mattielli, N., Goderis, S., et al. 2016. Mobility During the Neolithic and Bronze Age in Northern Ireland Explored Using Strontium Isotope Analysis of Cremated Human Bone. American Journal of Physical Antbropology, 160: 397413. https://doi.org/10.1002/ajpa.22977

Snoeck, C., Ryan, S., Pouncett, J., Pellegrini, M., Claeys, P., Wainwright, A.N., et al. 2020. Towards a Biologically Available Strontium Isotope Baseline for Ireland. Science of The Total Environment, 712: 136248. https://doi.org/10.1016/j.scitotenv.2019.136248

Thomas, J. 2013. The Birth of Neolithic Britain: An Interpretive Account. Oxford: Oxford University Press.

Tresset, A. 2015. Moving Animals and Plants in the Early Neolithic of North-Western Europe. In: C. Fowler, J. Harding \& D. Hofmann, eds. The Oxford Handbook of Neolithic Europe. Oxford: Oxford University Press. pp. 121-38.

Tresset, A. \& Vigne, J.D. 2011. Last HunterGatherers and First Farmers of Europe. Comptes rendus biologies, 334: 182-89. https://doi.org/10.1016/j.crvi.2010.12.010

Valentine, B., Kamenov, G.D., Kenoyer, J.M., Shinde, V., Mushrif-Tripathy, V., Otarola-Castillo, E. \& Krigbaum, J. 2015. Evidence for Patterns of Selective Urban Migration in the Greater Indus Valley (2600-1900 BC): A Lead and Strontium Isotope Mortuary Analysis. PLOS ONE, 10 (4): e0123103. https://doi.org/10.1371/ journal.pone. 0123103

Vyner, B. \& Wall, I. eds. 2011. A Neolithic Cairn at Whitwell, Derbyshire. Derbyshire Archaeological Journal, 131.

Walker, K. 2018. Axe-heads and Identity: An Investigation into the Roles of Imported Axe-heads in Identity Formation in Neolithic Britain. Oxford: Archaeopress.

Waterman, A.J., Peate, D.W., Silva, A.M. \& Thomas, J.T. 2014. In Search of Homelands: Using Strontium Isotopes to Identify Biological Markers of Mobility in Late Prehistoric Portugal. Journal of Archaeological Science, 42: 119-27. https://doi.org/10.1016/j.jas. 2013.11.004

Whittle, A., Healy, F. \& Bayliss, A. eds. 2011. Gathering Time: Dating the Early Neolithic Enclosures of Southern Britain and Ireland. Oxford: Oxbow.

Willmes, M., Bataille, C.P., James, H.F., Moffat, I., McMorrow, L., Kinsley, L., 
et al. 2018. Mapping of Bioavailable Strontium Isotope Ratios in France for Archaeological Provenance Studies. Applied Geochemistry, 90: 75-86. https:// doi.org/10.1016/j.apgeochem.2017.12.025

Willmes, M., McMorrow, L., Kinsley, L., Armstrong, R., Aubert, M., Eggins S., et al. 2013. The IRHUM (Isotopic Reconstruction of Human Migration) Database: Bioavailable Strontium Isotope Ratios for Geochemical Fingerprinting in France. Earth Systems Science Data Discussions, 6: 761-77. https://doi.org/10. 5194/essd-6-117-2014

Wright, L.E. \& Schwarcz, H.P. 1998. Stable Carbon and Oxygen Isotopes in Human Tooth Enamel: Identifying Breastfeeding and Weaning in Prehistory. American Journal of Physical Anthropology, 106: 1-18. https://doi.org/10.1002/(SICI)1096-8644 (199807)106:3\%3C411::AID-AJPA16\% 3E3.0.CO;2-3

\section{Biographical Notes}

Samantha Neil is a research scientist specializing in isotope geochemistry and bioarchaeology. Her work focuses on use of isotope analysis for geographic provenancing and the study of palaeodietary, climatic, and environmental change in the past.

Address: Samantha Neil, School of Archaeology, University of Oxford, 36 Beaumont Street, Oxford, OX1 2PG, UK. [email: samantha.neil@arch.ox.ac.uk]. ORCID: 0000-0002-8850-8719.

Jane Evans is a research scientist at the British Geological Survey, a visiting professor at School of Archaeology and Ancient History at Leicester University and an honorary professor at the Department of Archaeology at Nottingham University. Her work focuses on the use of isotope signatures to characterize faunal movement and migration in the archaeological record.

Address: Jane Evans, National Environmental Isotope Facility, Keyworth, Nottingham, NG12 5GG, UK. [email: je@bgs.ac.uk]. ORCID: 0000-0003-3667494X.

Janet Montgomery is a professor of bioarchaeology specializing in the isotopic and elemental analysis of humans and animals, and fundamental studies which underpin the interpretation of the data. She undertook the first combined strontium and lead isotope analysis of archaeological human remains to investigate migration and mobility for her doctoral research. Her research spans the Mesolithic to the nineteenth century $\mathrm{AD}$ and is focused primarily on European populations.

Address: Janet Montgomery, Durham University, Department of Archaeology, South Road, Durham, DH1 3LE, UK. [email: janet.montgomery@durham.ac.uk]. ORCID: 0000-0001-6729-3088.

Chris Scarre is professor of archaeology with research focusing on the Neolithic archaeology of western Europe, and in particular the relationship between monumentality, society and landscape. He has been involved in the excavation of megalithic chambered tombs in Portugal, France and the Channel Islands, and has a special interest in their origins and interregional connections.

Address: Chris Scarre, Durham University, Department of Archaeology, South Road, Durham, DH1 3LE, UK. [email: chris. scarre@durham.ac.uk]. ORCID: 00000002-7157-6539. 


\section{Données isotopiques sur le mouvement de populations humaines au Néolithique ancien dans le centre de l'Angleterre}

Les rapports isotopiques de l'émail des dents appartenant à dix individus ensevelis dans un long cairn à Whitwell dans le centre de l'Angleterre ont été analysés pour établir d'où provenait l'alimentation de ces individus pendant leur enfance. Cinq individus ont une faible concentration de strontium (11-66 ppm) et un taux élevé de ${ }^{87} \mathrm{Sr}{ }^{86} \mathrm{Sr}$ (0.7164-0.7212). Trois individus ont une proportion relativement faible de ${ }^{87} \mathrm{Sr}{ }^{86} \mathrm{Sr}(0.712-0.711)$ et des concentrations de strontium comprises entre 54 et $109 \mathrm{ppm}$. Deux individus possèdent des valeurs isotopiques de strontium qui comblent l'écart entre les compositions isotopiques de ces deux groupes. On rencontre rarement des valeurs élevées de ${ }^{87} \mathrm{Sr}{ }^{86} \mathrm{Sr}$ dans l'émail de dents humaines et il nous faut exclure une source dans la biosphère du centre de l'Angleterre. Les valeurs des isotopes de l'oxygène sont proches de celles que contiennent les restes archéologiques de populations humaines que l'on retrouve dans les sépultures des régions tempérées d'Europe continentale. Les résultats des analyses isotopiques du strontium pourraient donc plaider en faveur d'une migration de groupes bumains au Néolithique ancien. Translation by Madeleine Hummler

Mots-clés: migration, Néolithique, Grande-Bretagne, strontium, oxygène, isotopes

\section{Isotopische Hinweise auf Bevölkerungsbewegungen im frühen Neolithikum im englischen Mittelland}

Die Isotopenverbältnisse im Zahnschmelz von zehn Individuen, die in einem langen Steinbügel in Whitwell im englischen Mittelland bestattet waren, wurden untersucht, um zu bestimmen, wo sie ibre Ernäbrung im Kindesalter erhalten hatten. Fünf Individuen hatten geringe Konzentrationen von Strontium (11-66 ppm) und hohe (0.7164-0.7212). Drei Individuen hatten relativ geringe ${ }^{87} \mathrm{Sr}{ }^{86} \mathrm{Sr}$ Verhältnisse (0.712-0.711) und Strontium Konzentrationen zwischen 54 und 109 ppm. Zwei Individuen hatten Strontium Isotopenwerte zwischen den Isotopenzusammensetzungen dieser zwei verschiedenen Gruppen. Hohe ${ }^{87} \mathrm{Sr}{ }^{86} \mathrm{Sr}$ Isotopenwerte kommen selten im menschlichen Zahnschmelz vor und Quellen innerhalb der mittelenglischen Biosphäre kommen nicht in Frage. Isotopenwerte von Sauerstoff sind mit denen, die in archäologisch aufgenommenen Bestattungen von Menschen in den gemäßigten Zonen des europäischen Festlands zu finden sind, vergleichbar. Die Ergebnisse der Strontium Isotopen Analyse können deshalb vielleicht als Indiz für Bevölkerungsberwegungen im Frübneolitbikum angesehen werden. Translation by Madeleine Hummler

Stichworte: Migration, Neolithikum, Großbritannien, Strontium, Sauerstoff, Isotopen 